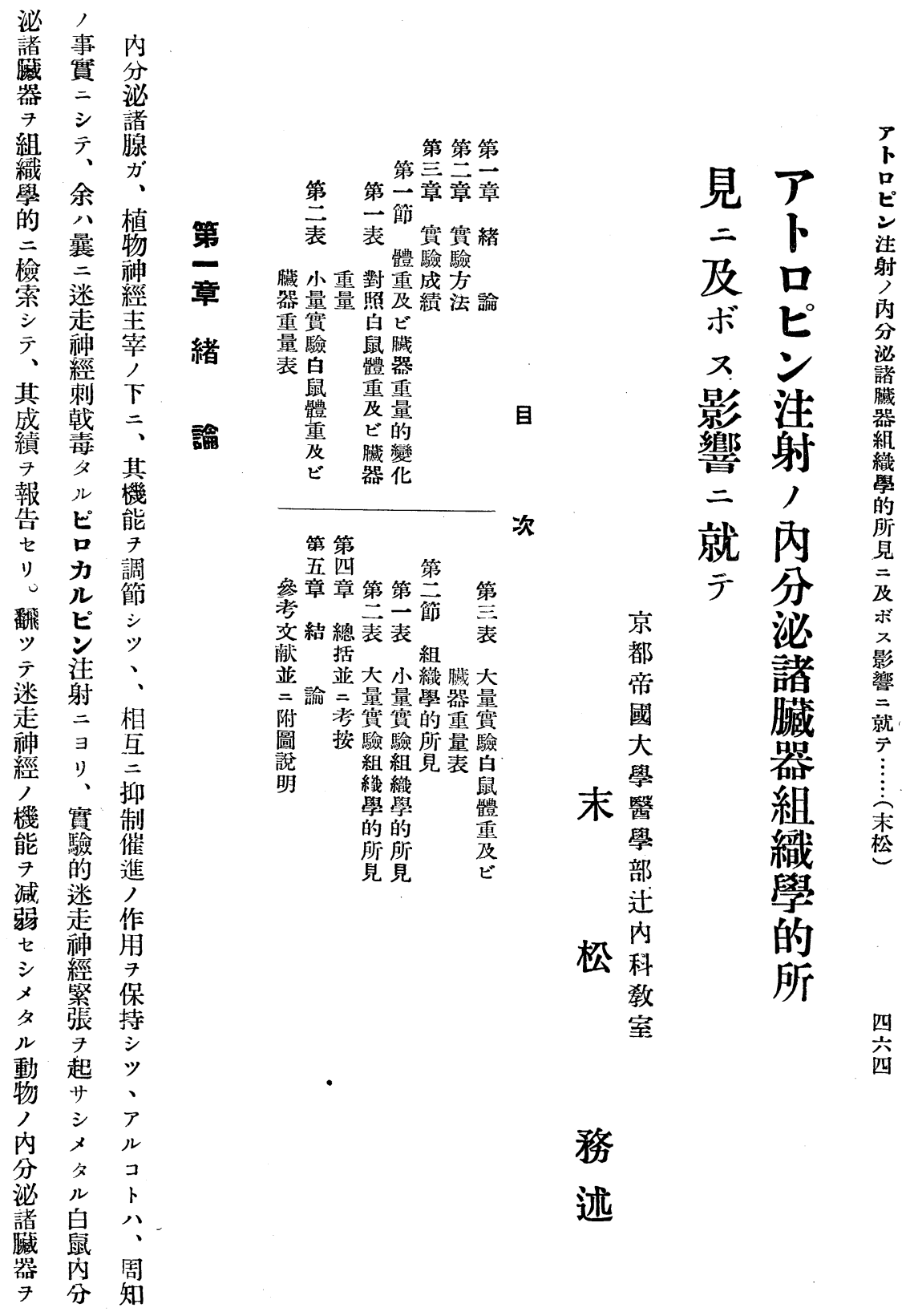




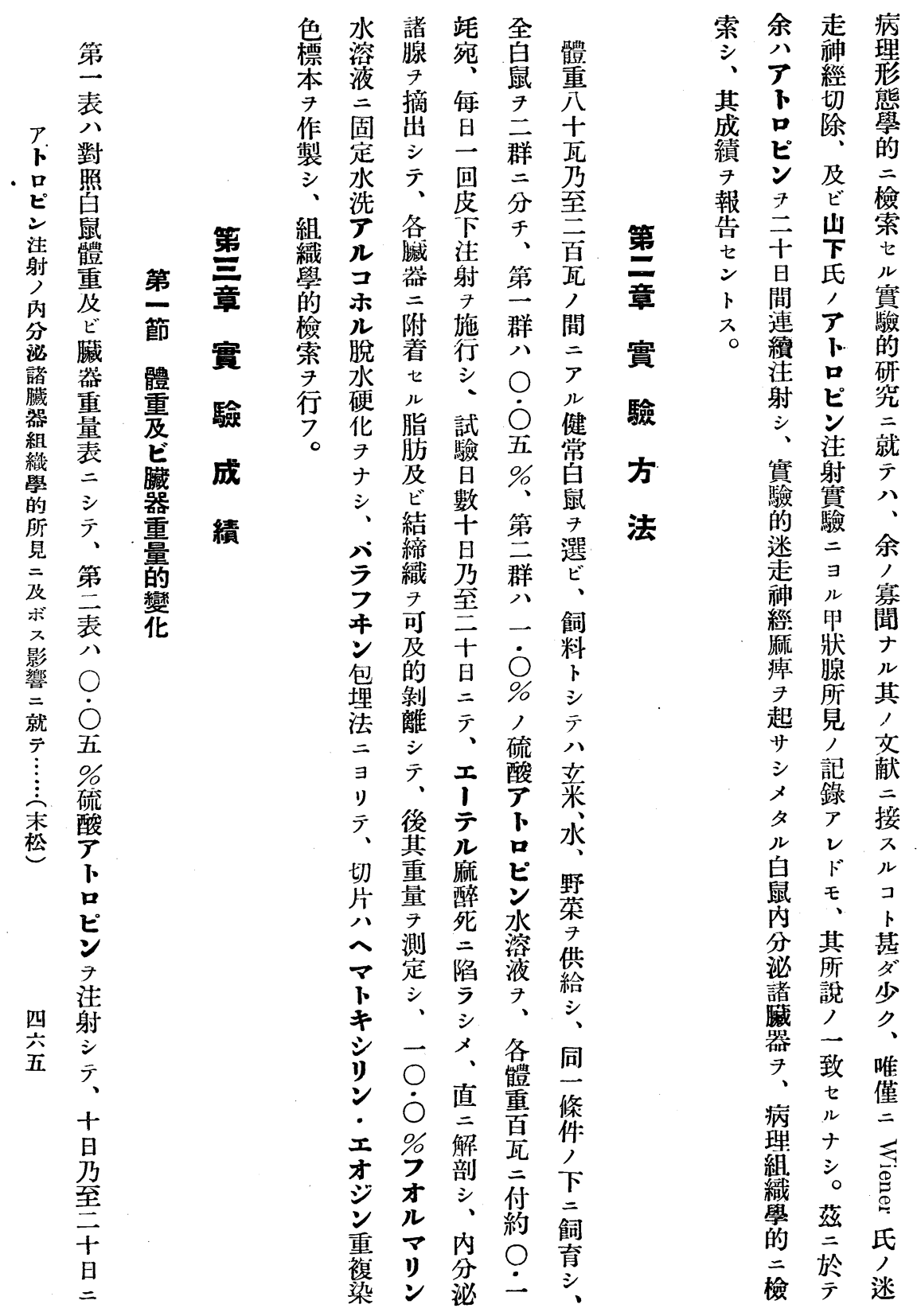



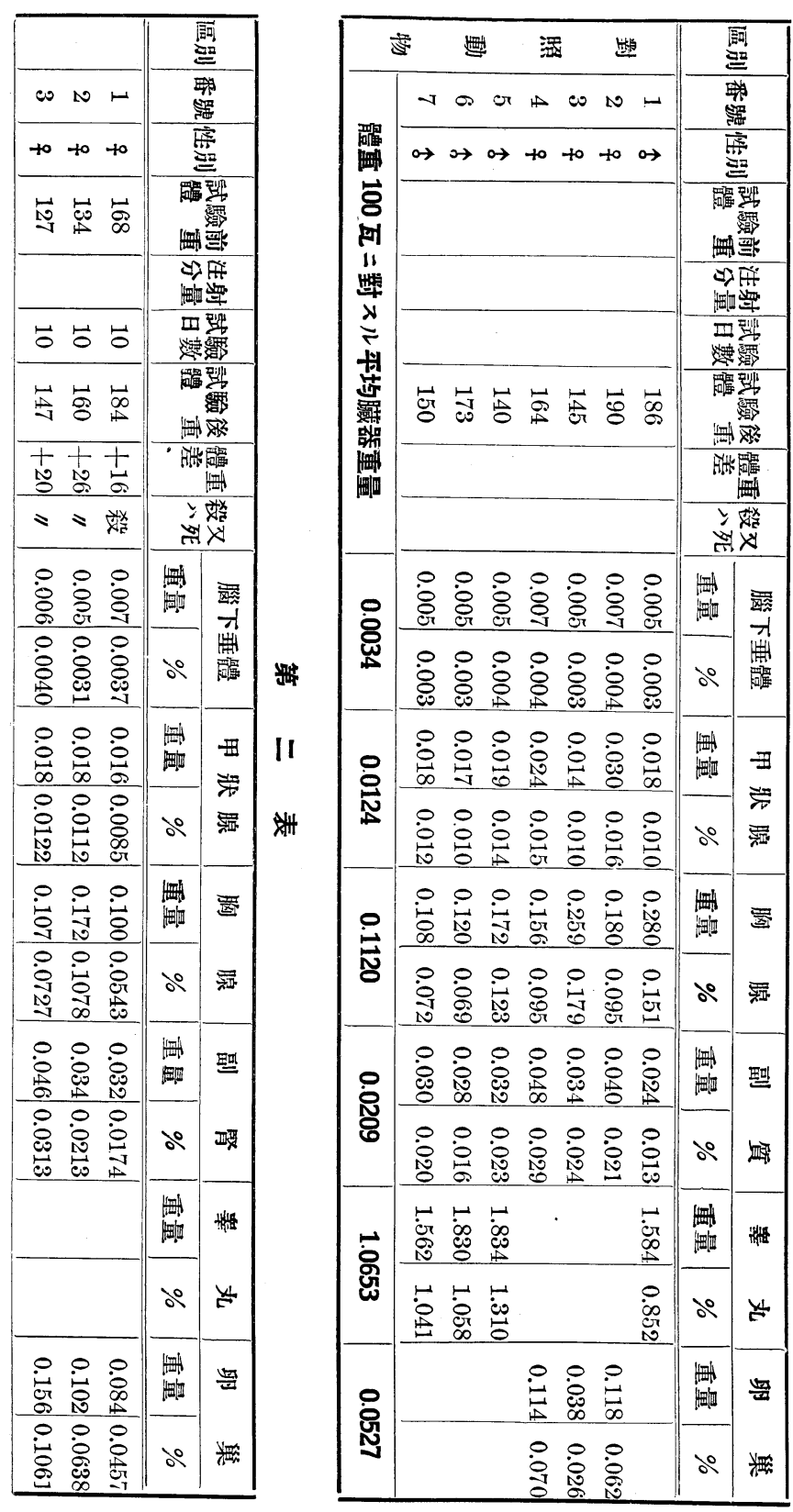

體 解

重 剖

及

藏

器重

量重

表及文 $\pi$

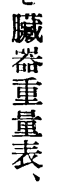

射

忿

慗

第

表

器

表

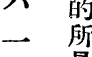

$\dot{0}$

$\%$

硫

酸渻

就

문

ピ

于

洼菘

,

$+$

星四

至突 

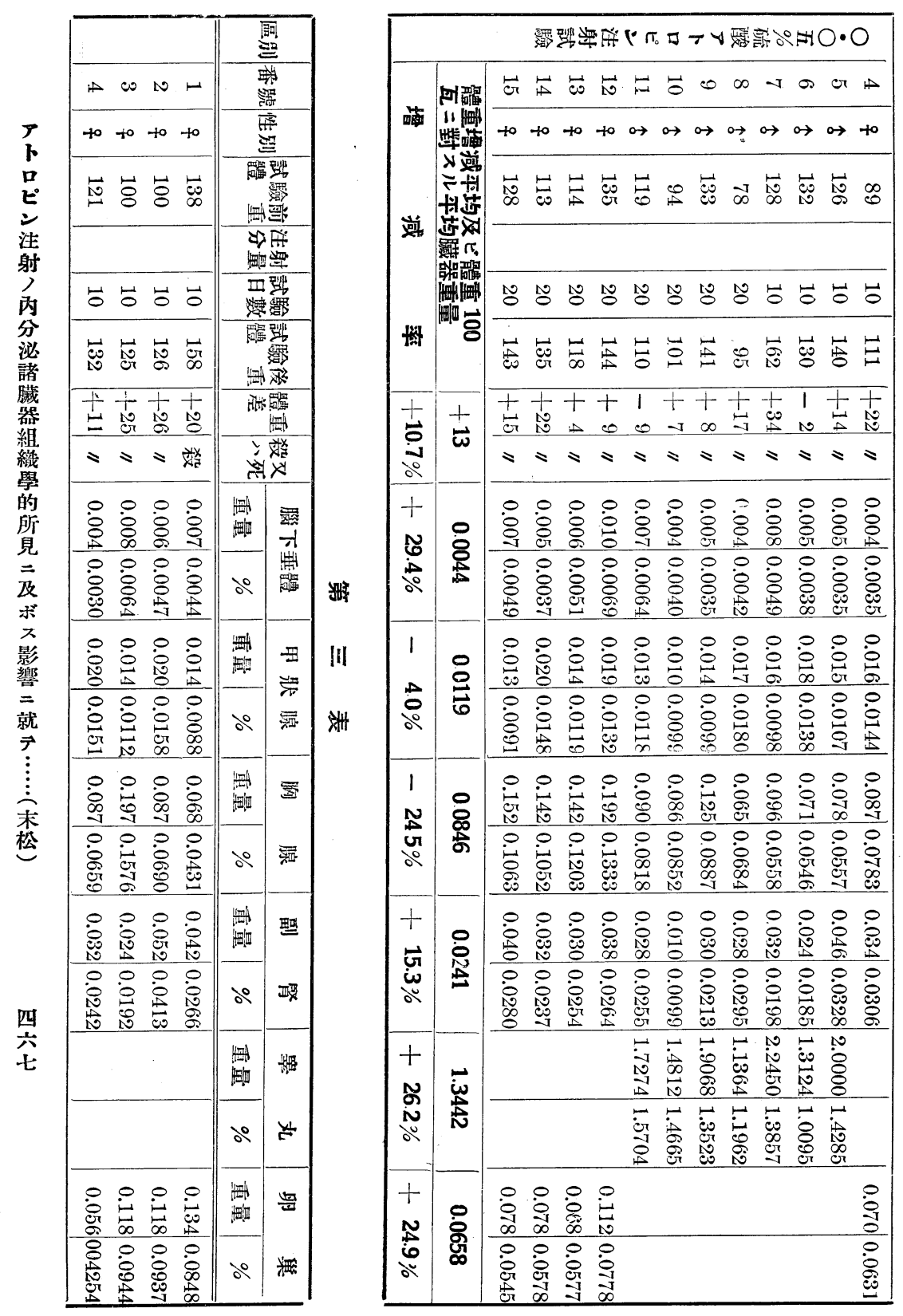


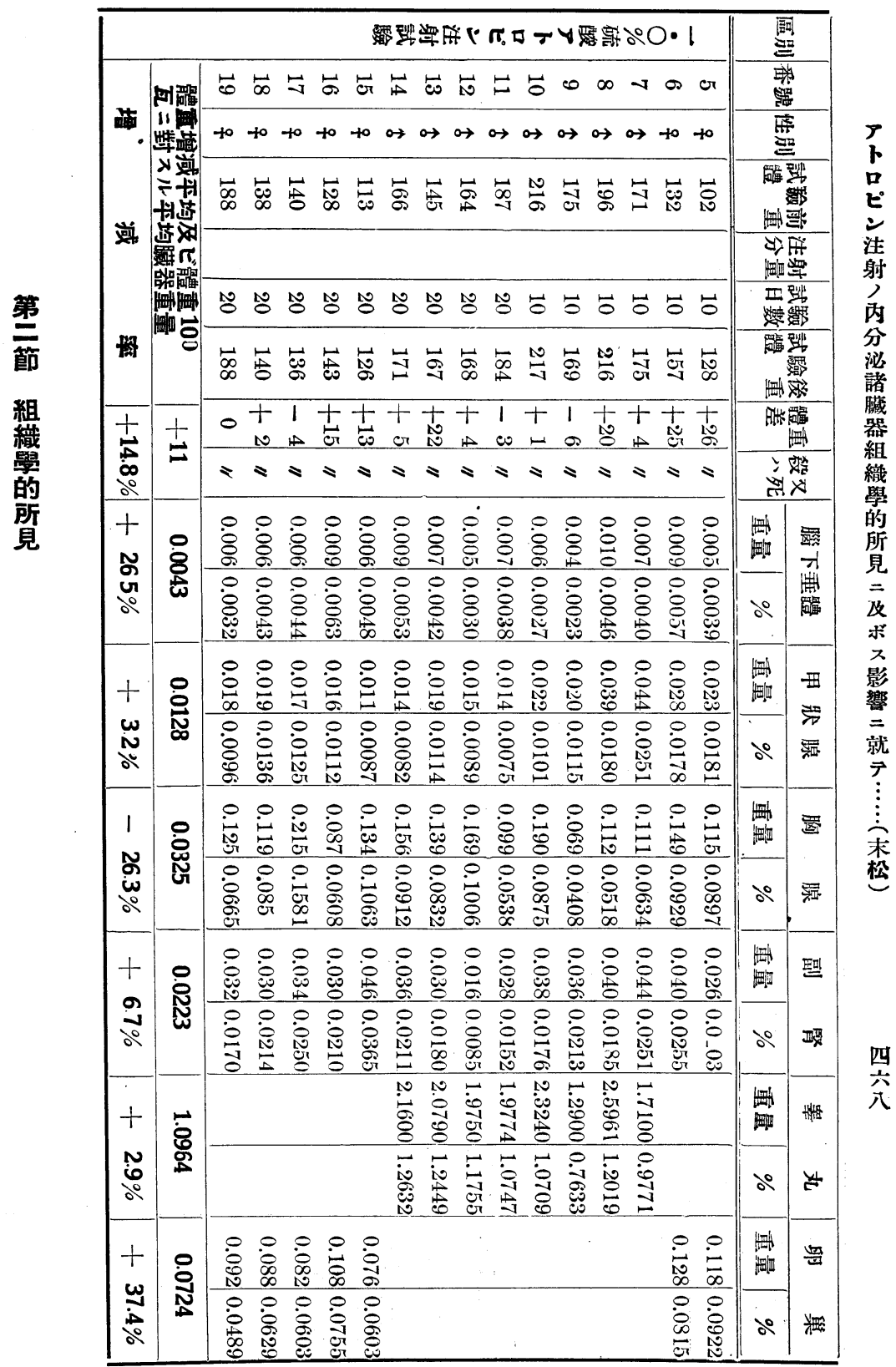




\begin{tabular}{|c|c|c|c|}
\hline \& 例 三 第 & + 例 二 第 & 古 例 一 第 & \\
\hline 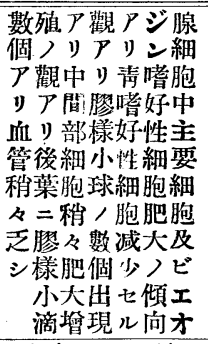 & 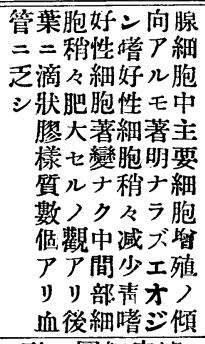 & 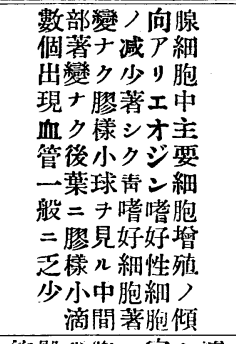 & $\begin{array}{l}\text { 垂 } \\
\text { 體 }\end{array}$ \\
\hline 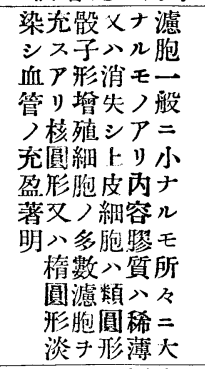 & 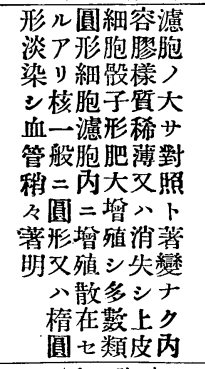 & 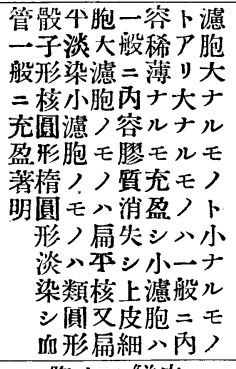 & 狀 \\
\hline 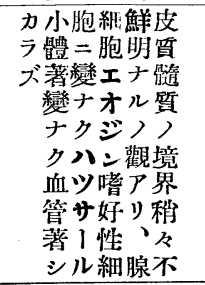 & 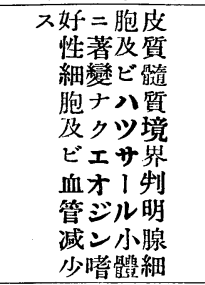 & 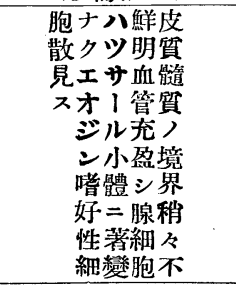 & 腺 \\
\hline 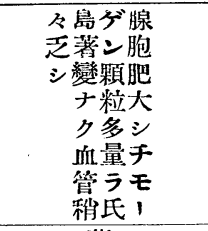 & $\begin{array}{c}\text { 著秒ゲ腺 } \\
\text { 變々シ胞 } \\
\text { ナそ顆肥 } \\
\text { シシ粒大 } \\
\text { ク多シ } \\
\text { ラ量チ } \\
\text { 氏血モ } \\
\text { 島管】 }\end{array}$ & 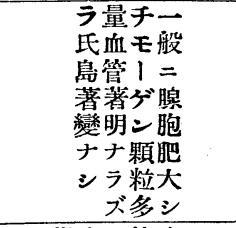 & 膵 \\
\hline $\begin{array}{l}\text { 著 } \\
\text { 變 } \\
\text { ナ } \\
\text { シ }\end{array}$ & 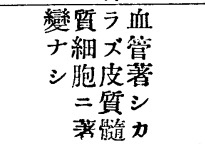 & 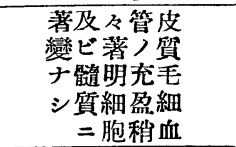 & $\begin{array}{l}\text { 副 } \\
\text { 堅 }\end{array}$ \\
\hline $\begin{array}{l}\text { 著ナ血 } \\
\text { 變儿管 } \\
\text { ナモ稍 } \\
\text { シ其々 } \\
\text { 他著 } \\
=\text { 明 }\end{array}$ & $\begin{array}{l}\text { 變著血 } \\
\text { 化シ管 } \\
\text { ナク稍 } \\
\text { シ其各 } \\
\text { 他态 } \\
\text { =盈 }\end{array}$ & $\begin{array}{l}\text { 著 } \\
\text { 變 } \\
\text { ナ } \\
\text { シ }\end{array}$ & $\begin{array}{l}\text { 八睪 } \\
\text { 卿 } \\
\text { 莜 及 }\end{array}$ \\
\hline
\end{tabular}




\begin{tabular}{|c|c|c|c|c|}
\hline 今 例七第 & 令 例六第 & 占 例五第 & 古 例四第 & 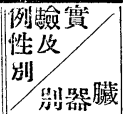 \\
\hline 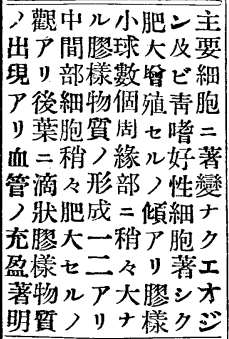 & 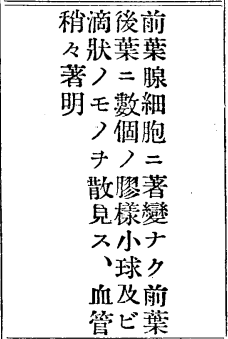 & 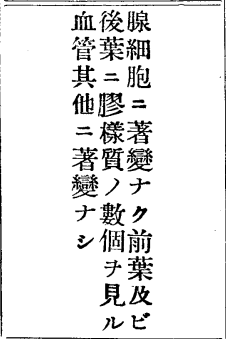 & 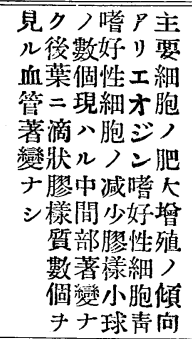 & $\begin{array}{l}\text { 腦 } \\
\text { 下 } \\
\text { 垂 } \\
\text { 體 }\end{array}$ \\
\hline 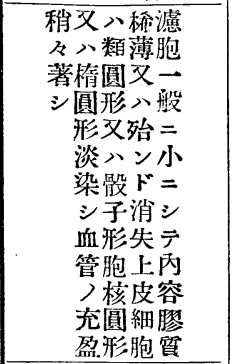 & 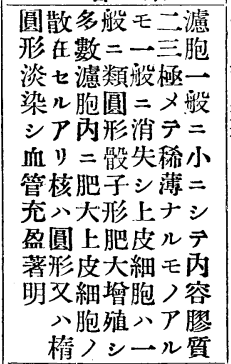 & 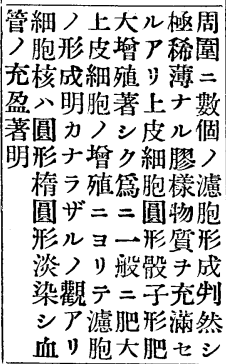 & 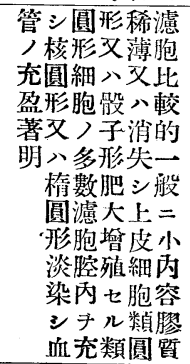 & 腺 \\
\hline 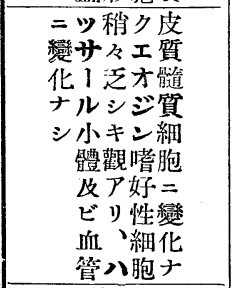 & 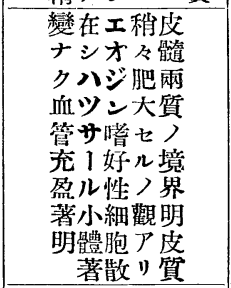 & 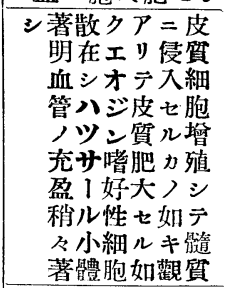 & 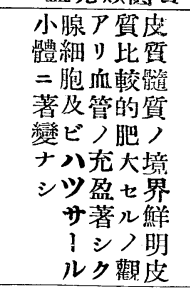 & 腺 \\
\hline 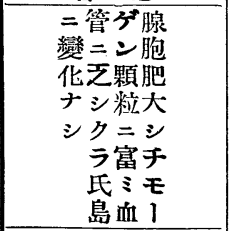 & 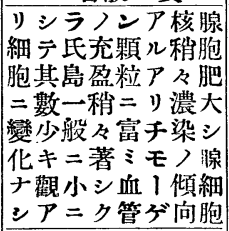 & $\begin{array}{c}\text { 島ハゲ腺 } \\
\text { 著著シ胞 } \\
\text { 變明顆肥 } \\
\text { ナナ粒大 } \\
\text { シラ多シ } \\
\text { ブ量チ } \\
\text { ラ血モ } \\
\text { 氏管l }\end{array}$ & $\begin{array}{c}\text { 變島血モ腺 } \\
\text { ナ及管 l 胞 } \\
\text { シビニデ稍 } \\
\text { 島乏゙ミ } \\
\text { 細シ顆肥 } \\
\text { 胞ク粒大 } \\
\text { ニシ多シ } \\
\text { 著氏量天 }\end{array}$ & 臟 \\
\hline $\begin{array}{l}\text { 著 } \\
\text { 變 } \\
\text { ナ } \\
\text { シ }\end{array}$ & $\begin{array}{l}\text { 著 } \\
\text { 變 } \\
\text { ナ } \\
\text { シ }\end{array}$ & $\begin{array}{l}\text { 著 } \\
\text { 變 } \\
\text { ナ } \\
\text { シ }\end{array}$ & $\begin{array}{c}\text { ナ細充皮 } \\
\text { シ胞盈罂 } \\
\text { 著血 } \\
\text { 著管 } \\
\text { 變ク }\end{array}$ & $\begin{array}{l}\text { 副 } \\
\text { 腎 }\end{array}$ \\
\hline $\begin{array}{l}\text { 著り明テ細 } \\
\text { 變其ナ精精 } \\
\text { ナ他ル系管 } \\
\text { シ細ノ形䍄 } \\
\text { 胞觀成接 } \\
\quad=ア \text { 著シ }\end{array}$ & $\begin{array}{l}\text { 著 } \\
\text { 變 } \\
\text { ナ } \\
\text { シ }\end{array}$ & 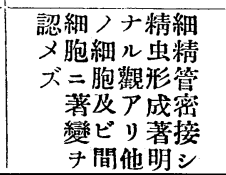 & $\begin{array}{l}\text { 萻 } \\
\text { 變 } \\
\text { ナ } \\
\text { シ }\end{array}$ & $\begin{array}{l}\text { 八睪 } \\
\text { 卵炕 } \\
\text { 巢又 }\end{array}$ \\
\hline
\end{tabular}




\begin{tabular}{|c|c|c|c|}
\hline 今 例一十第 & 例十第 & 例 九第 & 例 八 第 \\
\hline 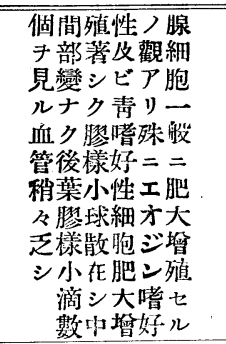 & 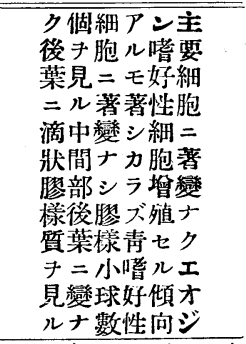 & 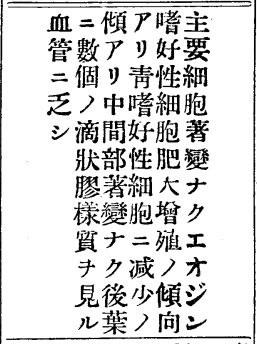 & 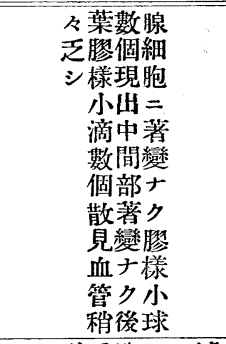 \\
\hline 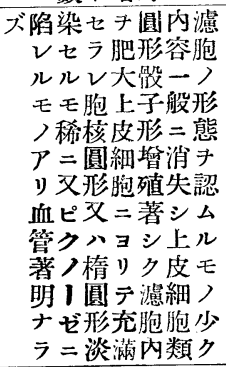 & 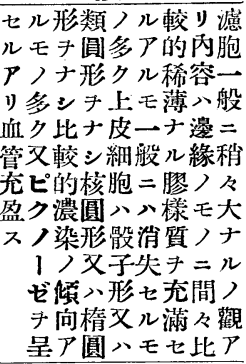 & 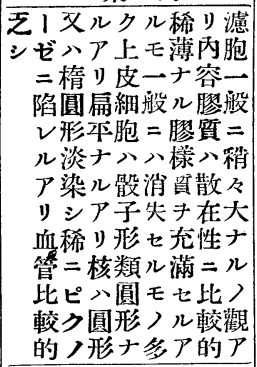 & 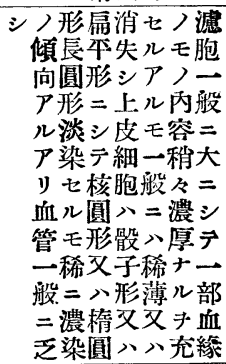 \\
\hline 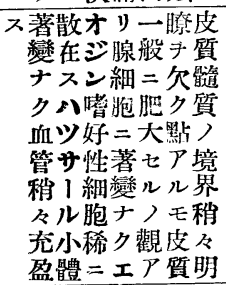 & 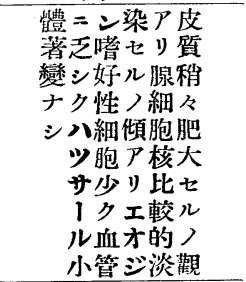 & 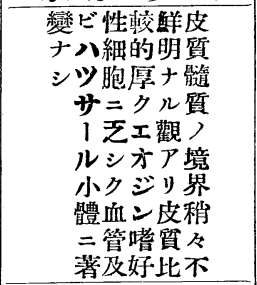 & 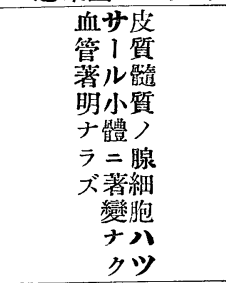 \\
\hline 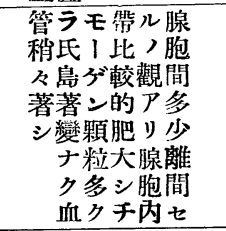 & 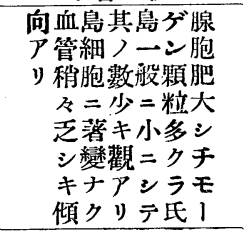 & $\begin{array}{l}\text { 血二テー } \\
\text { 管富チ般 } \\
\text { 三モニ } \\
\text { 著ラI腺 } \\
\text { 戀氏ぶ胞 } \\
\text { ナ島ン肥 } \\
\text { シ及顆大 } \\
\text { ビ粒シ }\end{array}$ & 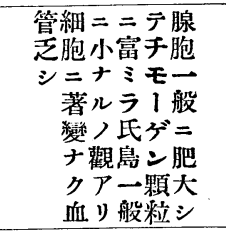 \\
\hline $\begin{array}{l}\text { 著 } \\
\text { 變 } \\
\text { ナ゙ } \\
\text { シ }\end{array}$ & $\begin{array}{l}\text { 著 } \\
\text { 變 } \\
\text { ナ } \\
\text { シ }\end{array}$ & $\begin{array}{l}\text { 著 } \\
\text { 變 } \\
\text { ナ } \\
\text { シ }\end{array}$ & $\begin{array}{l}\text { 著 } \\
\text { 變 } \\
\text { ナ } \\
\text { シ }\end{array}$ \\
\hline $\begin{array}{l}\text { 著 } \\
\text { 戀 } \\
\text { ナ } \\
\text { シ }\end{array}$ & $\begin{array}{l}\text { 著 } \\
\text { 蔹 } \\
\text { ナ } \\
\text { シ }\end{array}$ & $\begin{array}{l}\text { 著 } \\
\text { 戀 } \\
\text { キ } \\
\text { 認 } \\
\text { メ } \\
\text { ブ }\end{array}$ & $\begin{array}{l}\text { 著 } \\
\text { 變 } \\
\text { ナ } \\
\text { シ }\end{array}$ \\
\hline
\end{tabular}




\begin{tabular}{|c|c|c|c|c|}
\hline 占 例五十第 & 古 例四十第 & + 例三十第 & 例二十第 & 例驗實 \\
\hline 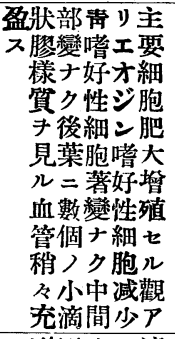 & 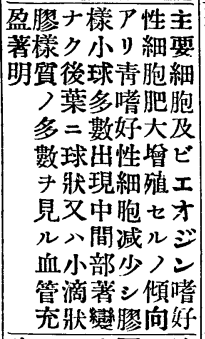 & 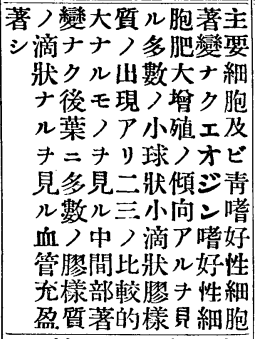 & 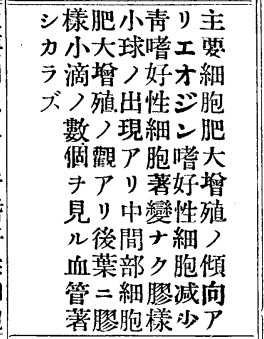 & $\begin{array}{l}\text { 下 } \\
\text { 垂 }\end{array}$ \\
\hline 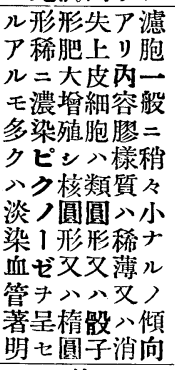 & 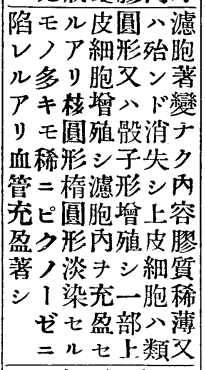 & 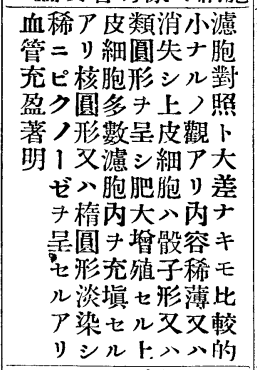 & 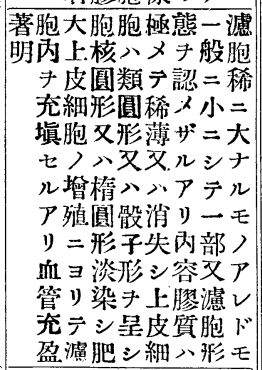 & 狀 \\
\hline $\begin{array}{l}\text { 第 } \\
+ \\
\text { 四 } \\
\text { 例 } \\
= \\
\text { 。略 } \\
\text { 及 } \\
\text { 同 } \\
\text { 沙 }\end{array}$ & 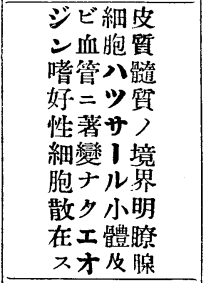 & 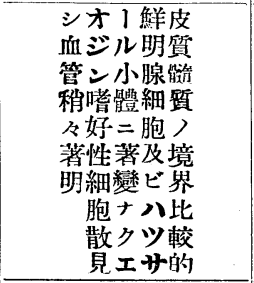 & 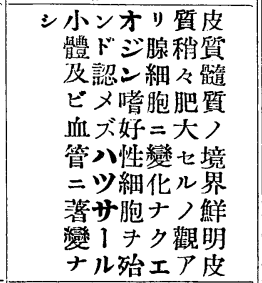 & 胸 \\
\hline $\begin{array}{c}\text { ジ第 } \\
+ \\
\text { 四 } \\
\text { 例 } \\
= \\
\text { 略 } \\
\text { \& } \\
\text { 同 }\end{array}$ & $\begin{array}{c}\text { 變氏 } 1 \text { 腺 } \\
\text { ナ島ぶ胞 } \\
\text { シ及ン肥 } \\
\text { ビ顆大 } \\
\text { 血粒シ } \\
\text { 管多テ } \\
\text { 量モ } \\
\text { 荎ラモ }\end{array}$ & 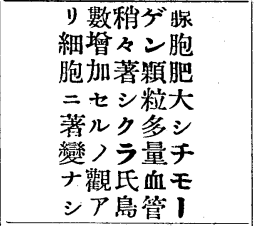 & 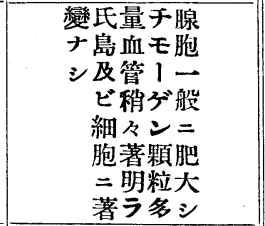 & 臟 \\
\hline $\begin{array}{l}\text { 著 } \\
\text { 變 } \\
\text { ナ } \\
\text { シ }\end{array}$ & $\begin{array}{l}\text { 著 } \\
\text { 變 } \\
\text { ナ } \\
\text { シ }\end{array}$ & 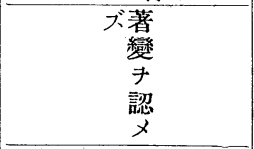 & 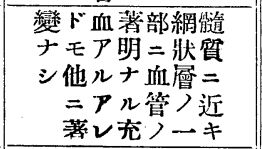 & $\begin{array}{l}\text { 副 } \\
\text { 腎 }\end{array}$ \\
\hline $\begin{array}{l}\text { 著 } \\
\text { 變 } \\
\text { ナ } \\
\text { シ }\end{array}$ & $\begin{array}{l}\text { 著 } \\
\text { 變 } \\
\text { ナ } \\
\text { シ }\end{array}$ & $\begin{array}{l}\text { シナ血 } \\
\text { ル管 } \\
\text { 外充 } \\
\text { 著盈 } \\
\text { 變䔔 } \\
\text { ナ明 } \\
\end{array}$ & $\begin{array}{r}\text { ナ゙ナ和 } \\
\text { シル管 } \\
\text { 充 } \\
\text { 外夃 } \\
\text { 變著 } \\
\text { 化明 } \\
\end{array}$ & $\begin{array}{l}\text { 八啐 } \\
\text { 卵丸 } \\
\text { 莜又 }\end{array}$ \\
\hline
\end{tabular}




\begin{tabular}{|c|c|c|c|c|}
\hline + 例四第 & 古 例 三第 & + 例 二 第 & 古 例 一 第 & 例 \\
\hline 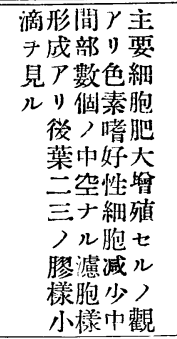 & 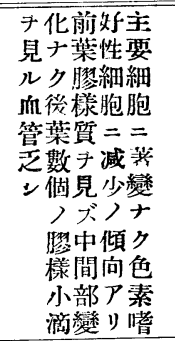 & 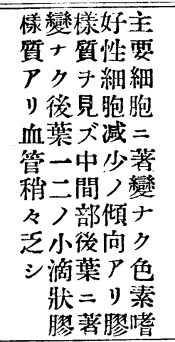 & 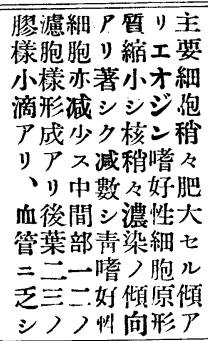 & $\begin{array}{l}\text { 腦 } \\
\text { 下 } \\
\text { 垂 }\end{array}$ \\
\hline 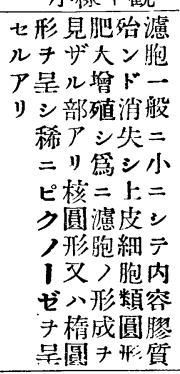 & 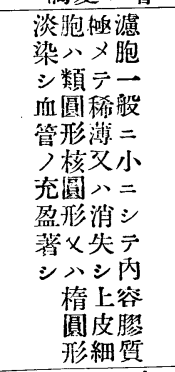 & 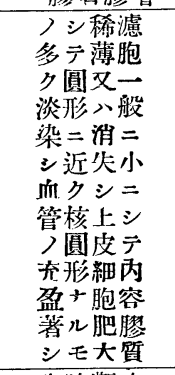 & 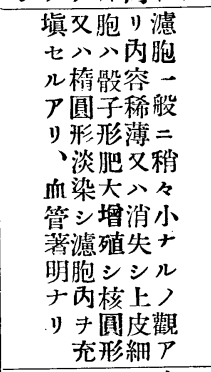 & 腺 \\
\hline 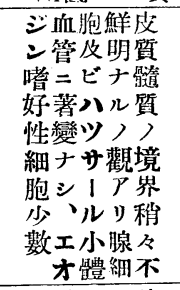 & 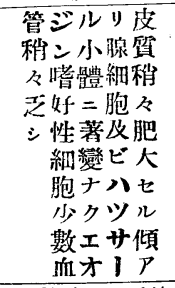 & 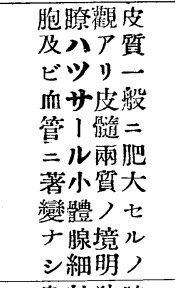 & 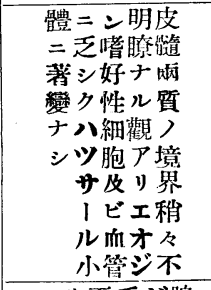 & 胸 \\
\hline 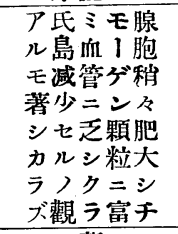 & 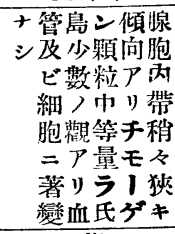 & 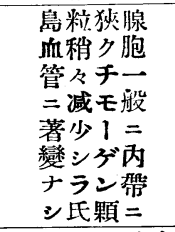 & 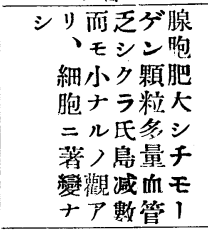 & 臟 \\
\hline $\begin{array}{l}\text { 著 } \\
\text { 變 } \\
\text { ナ } \\
\text { シ }\end{array}$ & $\begin{array}{l}\text { 著 } \\
\text { 變 } \\
\text { ナ } \\
\text { シ }\end{array}$ & 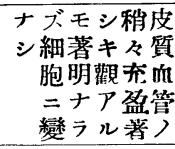 & $\begin{array}{l}\text { 著々血 } \\
\text { 變著管 } \\
\text { ナシ莽 } \\
\text { シキ盈 } \\
\text { 外稍 }\end{array}$ & $\begin{array}{l}\text { 副 } \\
\text { 腎 }\end{array}$ \\
\hline $\begin{array}{c}\text { シナ血 } \\
\text { 管 } \\
\text { 外昪 } \\
\text { 變 } \\
\text { 华著 } \\
\text { ナ明 }\end{array}$ & $\begin{array}{l}\text { 薯 } \\
\text { 戀 } \\
ナ \\
\text { シ }\end{array}$ & $\begin{array}{l}\text { ブキ血 } \\
\text { 外管 } \\
\text { 變稍 } \\
\text { 华及 } \\
\text { キ著 } \\
\text { 見シ } \\
\end{array}$ & 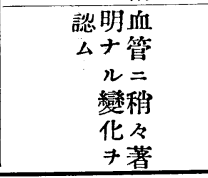 & 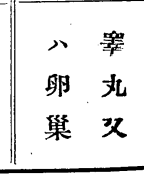 \\
\hline
\end{tabular}




\begin{tabular}{|c|c|c|c|c|}
\hline 今 例 八 第 & 占 例 七第 & 市 例六第 & \& 例 五 第 & 怔 \\
\hline 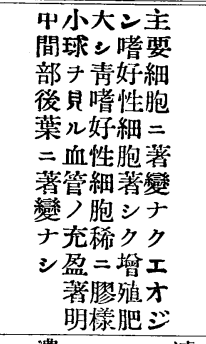 & 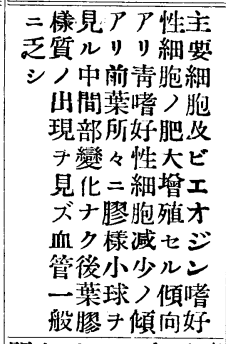 & 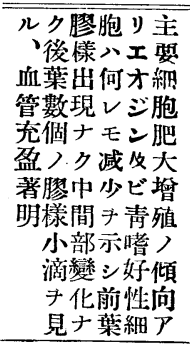 & 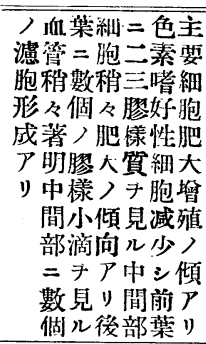 & $\begin{array}{l}\text { 瑫 } \\
\text { 下 } \\
\text { 垂 } \\
\text { 體 }\end{array}$ \\
\hline 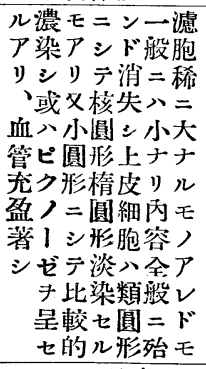 & 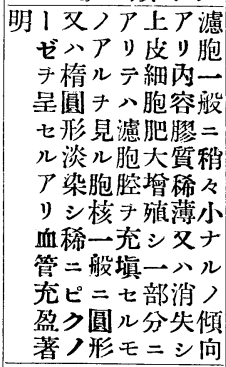 & 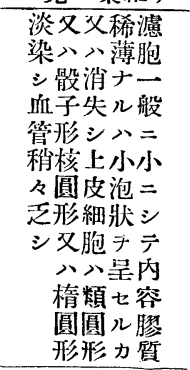 & 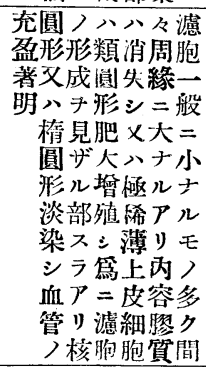 & 狀 \\
\hline 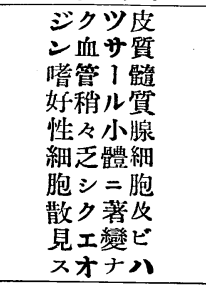 & 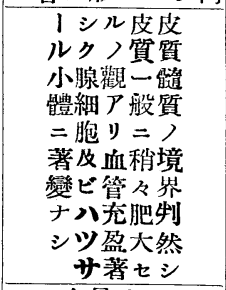 & 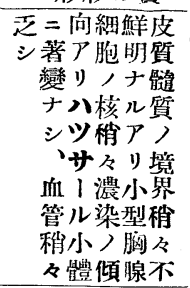 & 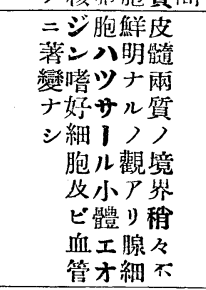 & 胸 \\
\hline $\begin{array}{l}\text { 變氏ぞノ腺腺 } \\
\text { ナ島ン傾細胞 } \\
\text { シ及顆向胞二 } \\
\text { ビ粒ア核搬 } \\
\text { 血二リ稍二 } \\
\text { 管富チ々肥 } \\
\text { シモ濃大 } \\
\text { 著ラリ染シ } \\
\end{array}$ & $\begin{array}{l}\text { 血量チ腺 } \\
\text { 管ラモ胞 } \\
\text { =氏 1- } \\
\text { 著島ぶ般 } \\
\text { 變細ン= } \\
\text { ナ胞顆肥 } \\
\text { シ文粒大 } \\
\text { ビ多シ }\end{array}$ & 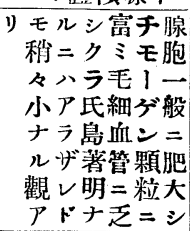 & 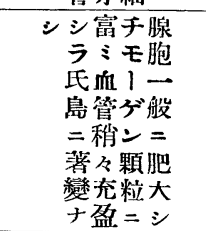 & 臟 \\
\hline $\begin{array}{c}\text { 變ド明㳘皮 } \\
\text { キモナ盈筧 } \\
\text { 見他ル稍血 } \\
\text { ズニアタ管 } \\
\text { 著レ著〉 }\end{array}$ & 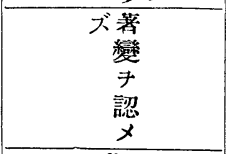 & $\begin{array}{l}\text { シル充毛 } \\
\text { 外盈細 } \\
\text { 艒著血 } \\
\text { 變明管 } \\
\text { ナナノ }\end{array}$ & $\begin{array}{l}\text { 著 } \\
\text { 變 } \\
\text { ナ } \\
\text { シ }\end{array}$ & $\begin{array}{l}\text { 副 } \\
\text { 腎 }\end{array}$ \\
\hline $\begin{array}{l}\text { 著 } \\
\text { 變 } \\
\text { ナ } \\
\text { シ }\end{array}$ & $\begin{array}{l}\text { 著 } \\
\text { 戀 } \\
\text { ナ } \\
\text { シ }\end{array}$ & $\begin{array}{l}\text { キ血 } \\
\text { 外管 } \\
\text { 葓充 } \\
\text { 變夃 } \\
\text { ナ著 } \\
\text { シ }\end{array}$ & $\begin{array}{l}\text { ナ明血 } \\
\text { シナ管 } \\
\text { ル } \\
\text { 外充 } \\
\text { 著盈 } \\
\text { 戀 }\end{array}$ & 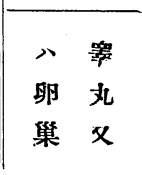 \\
\hline
\end{tabular}




\begin{tabular}{|c|c|c|c|}
\hline 占例二十第 & 占 例一十笎 & 令 例十第 & 今 例 九 第 \\
\hline 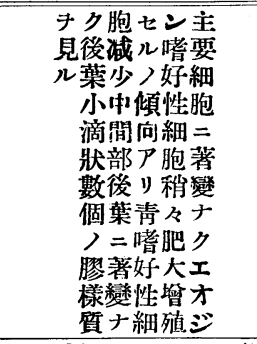 & 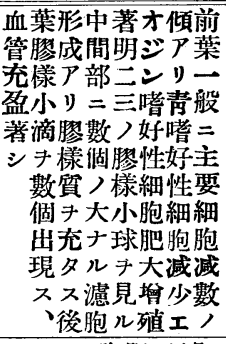 & 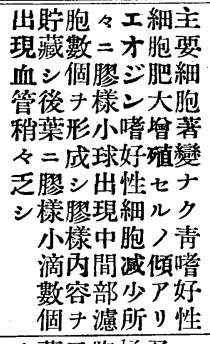 & 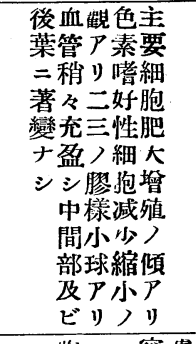 \\
\hline 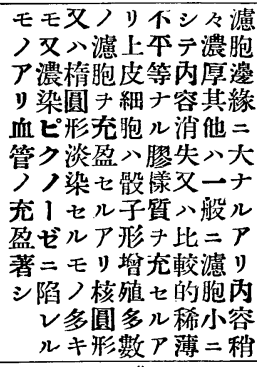 & 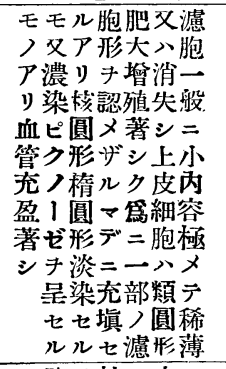 & 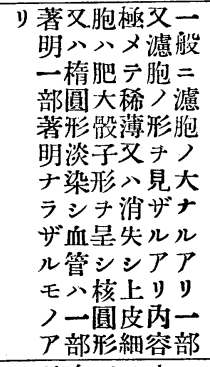 & 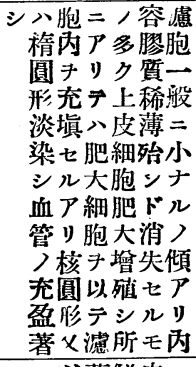 \\
\hline 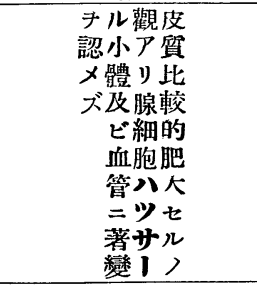 & 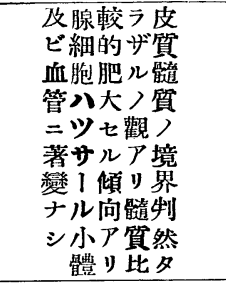 & 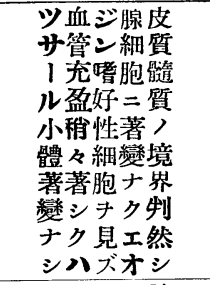 & 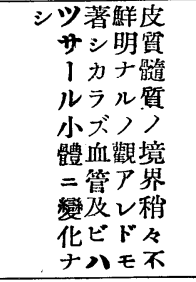 \\
\hline 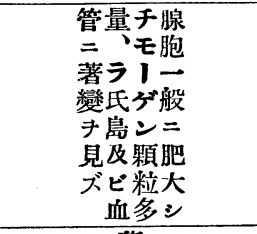 & $\begin{array}{l}\text { 變島乡゙腺 } \\
\text { 化及ン胞 } \\
\text { ナビ顆肥 } \\
\text { シ血粒大 } \\
\text { 管多シ } \\
\text { 獎量チ } \\
\text { 態シモ } \\
\text { =氏 } \\
\text { =氏 }\end{array}$ & 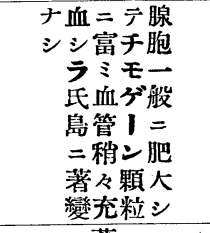 & 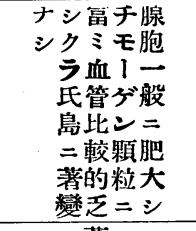 \\
\hline $\begin{array}{l}\text { 著 } \\
\text { 變 } \\
ナ \\
\text { ン }\end{array}$ & $\begin{array}{l}\text { 箸 } \\
\text { 戀 } \\
\text { ナ } \\
\text { シ }\end{array}$ & $\begin{array}{l}\text { 著 } \\
\text { 變 } \\
\text { ナ } \\
\text { シ }\end{array}$ & 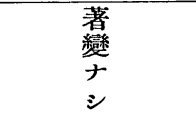 \\
\hline $\begin{array}{l}\text { 著 } \\
\text { 變 } \\
\text { ナ } \\
\text { シ }\end{array}$ & $\begin{array}{l}\text { 著 } \\
\text { 變 } \\
\text { ナ } \\
\text { シ }\end{array}$ & $\begin{array}{c}\text { 著 } \\
\text { 變 } \\
\text { ナ } \\
\text { シ }\end{array}$ & $\begin{array}{l}\text { 薯 } \\
\text { 變 } \\
\text { ナ } \\
\text { シ }\end{array}$ \\
\hline
\end{tabular}




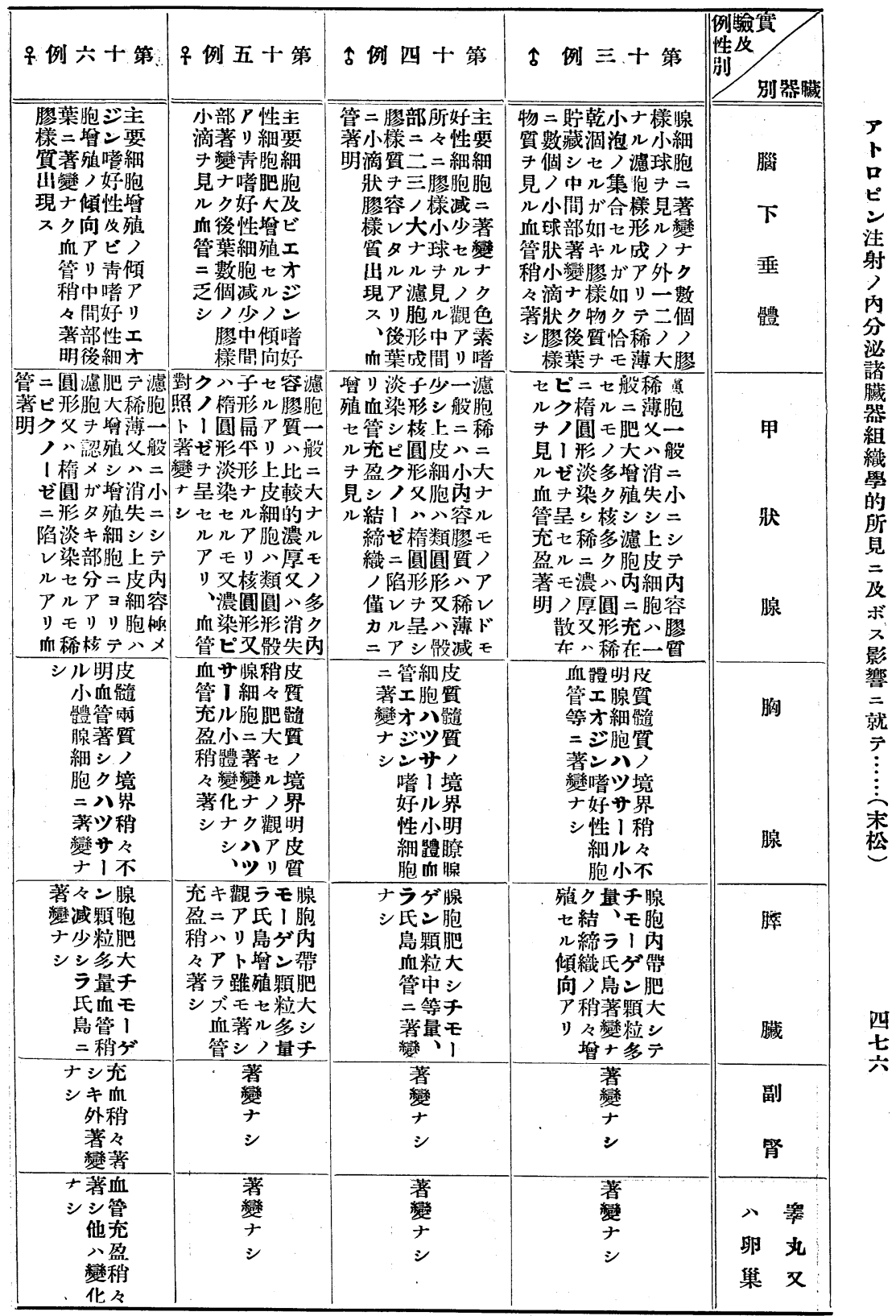




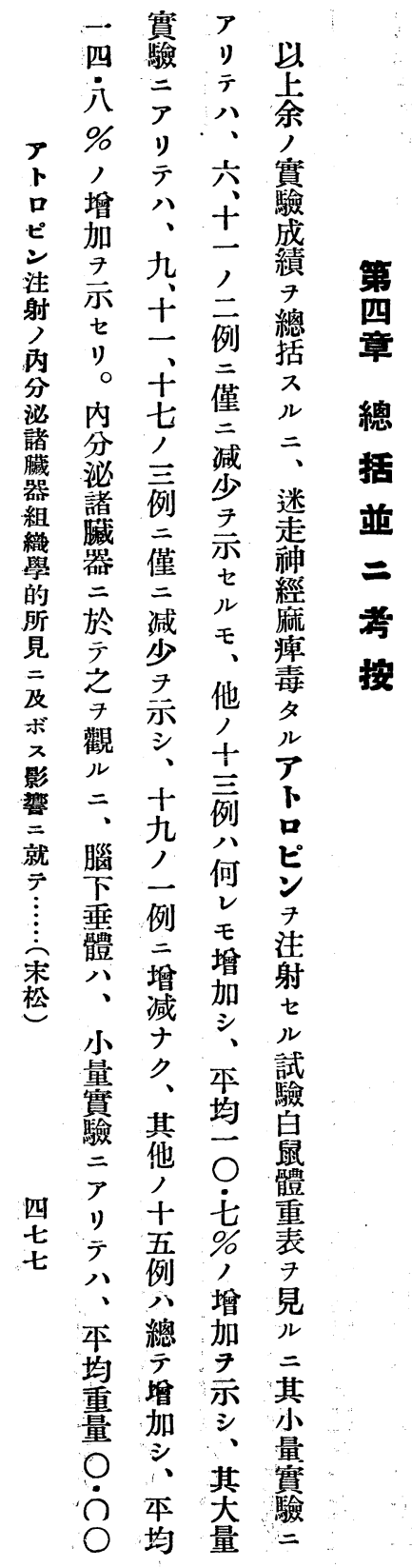

\begin{tabular}{|c|c|c|}
\hline 呆例九十第 & 古例八十第 & 字例七十第 \\
\hline 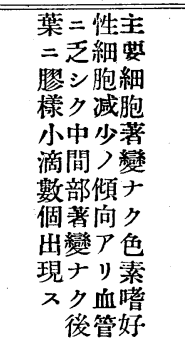 & 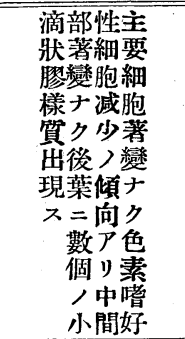 & 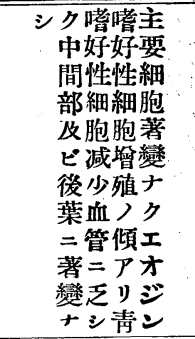 \\
\hline
\end{tabular}

血ク比形充稍濾著ノ八形稀一濾ゼ圆認キ增薄般濾

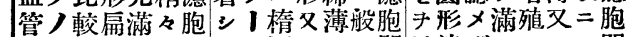
稍〉的平シ濃一ゼ圓ハ文二間呈淡ザセシハハ間

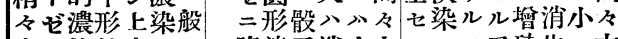
充染核皮〉 $=$ 陷淡子消小大几七モア殖失二大 盈星七圓細傾中 染形失ナナアルノリ細シシナ スセル形胞ア等 ルセキシルル リモアテ胞上テル 几傾楕ハリ大アル呈上傾モ、稀り濾入皮內モ モP圓類テ內 リモシ皮问〉血二核胞多細容〉 ノリ形圓濾容 血稀核細アア管ピハノ數胞膠ア

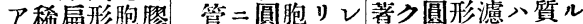
リ本骰內質 旮ピ形類内ド明ノ形成胞肥ハモ

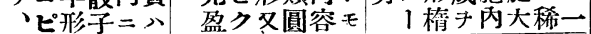

\begin{tabular}{|c|c|c|}
\hline 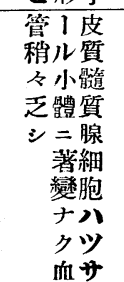 & 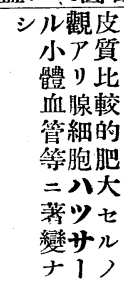 & $\begin{array}{c}\text { シ小ア皮 } \\
\text { 體リ哯 } \\
\text { Z腺稍 } \\
\text { ビ細々 } \\
\text { 血胞肥 } \\
\text { 管ハ大 } \\
\text { =ツ七 } \\
\text { 荖サル } \\
\text { 變 I } \\
\text { ナル觀 }\end{array}$ \\
\hline 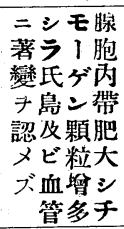 & 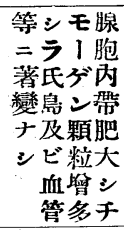 & $\begin{array}{c}\text { 稍島ぶ腺 } \\
\text { タ著ン胞 } \\
\text { 充變顆肥 } \\
\text { 盈ナ粒大 } \\
\text { 傾ク、多シ } \\
\text { 、量天 } \\
\text { リ血ラモ } \\
\text { 管氏। }\end{array}$ \\
\hline $\begin{array}{l}\text { 著 } \\
\text { 變 } \\
\text { ナ } \\
\text { シ }\end{array}$ & $\begin{array}{c}\text { 著 } \\
\text { 變 } \\
\text { ナ } \\
\text { シ }\end{array}$ & $\begin{array}{l}\text { 著 } \\
\text { 縎 } \\
\text { ナ } \\
\text { シ }\end{array}$ \\
\hline $\begin{array}{l}\text { 著 } \\
\text { 變 } \\
\text { ナ } \\
\text { シ }\end{array}$ & $\begin{array}{c}\text { 著 } \\
\text { 變 } \\
\text { 于 } \\
\vdots \\
\end{array}$ & $\begin{array}{l}\text { 奢 } \\
\text { 變 } \\
\text { ナ } \\
\text { シ }\end{array}$ \\
\hline
\end{tabular}




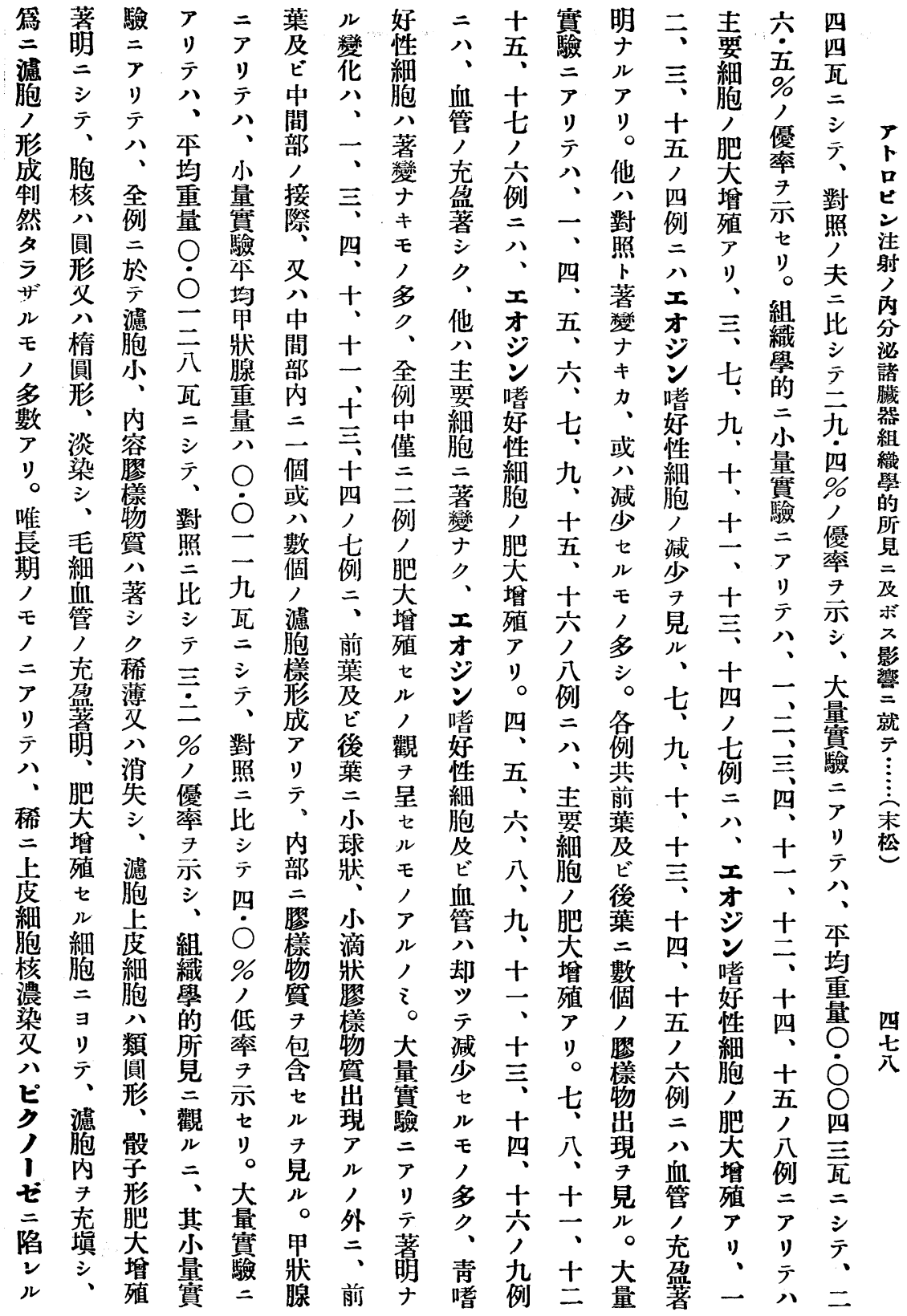




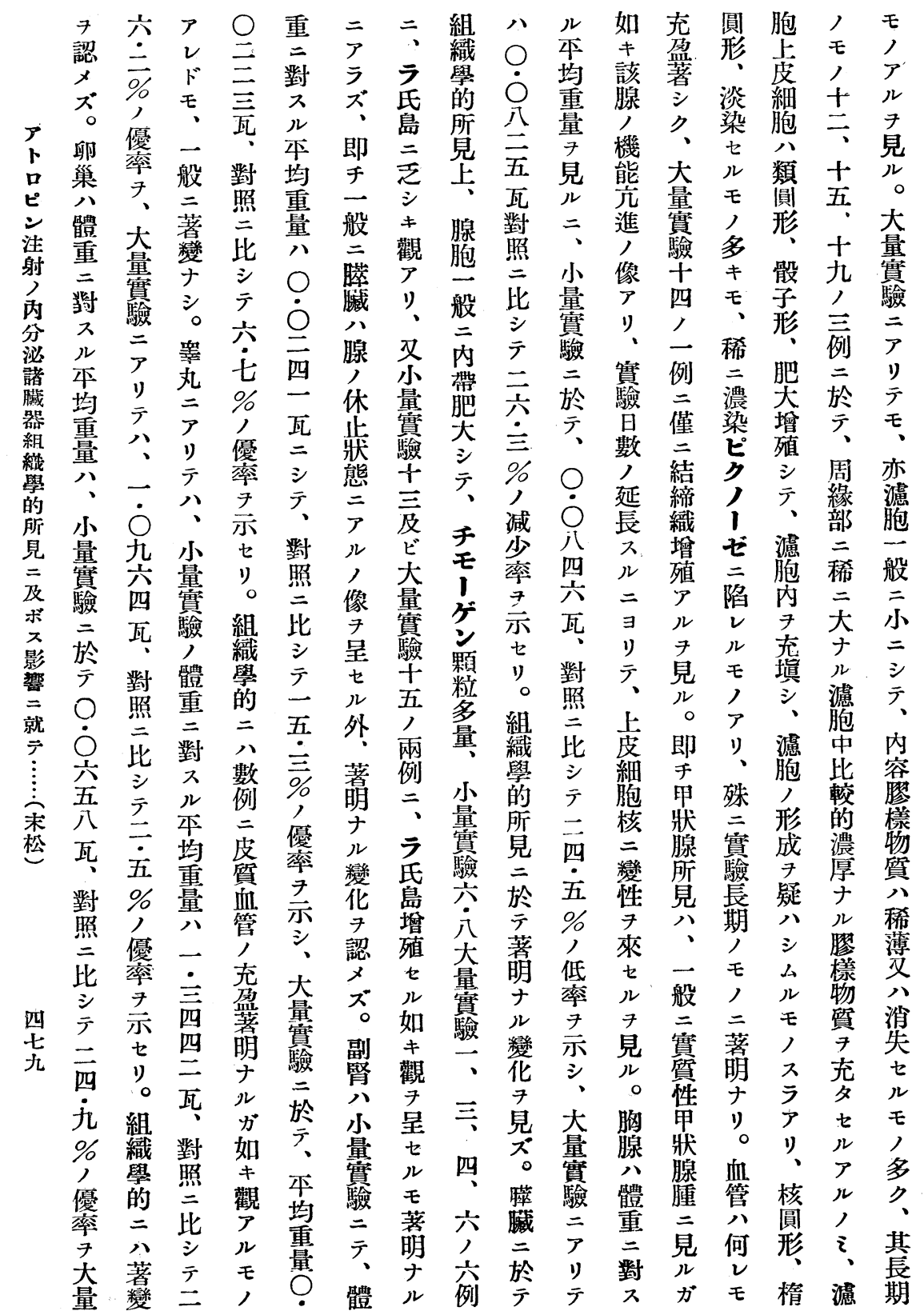




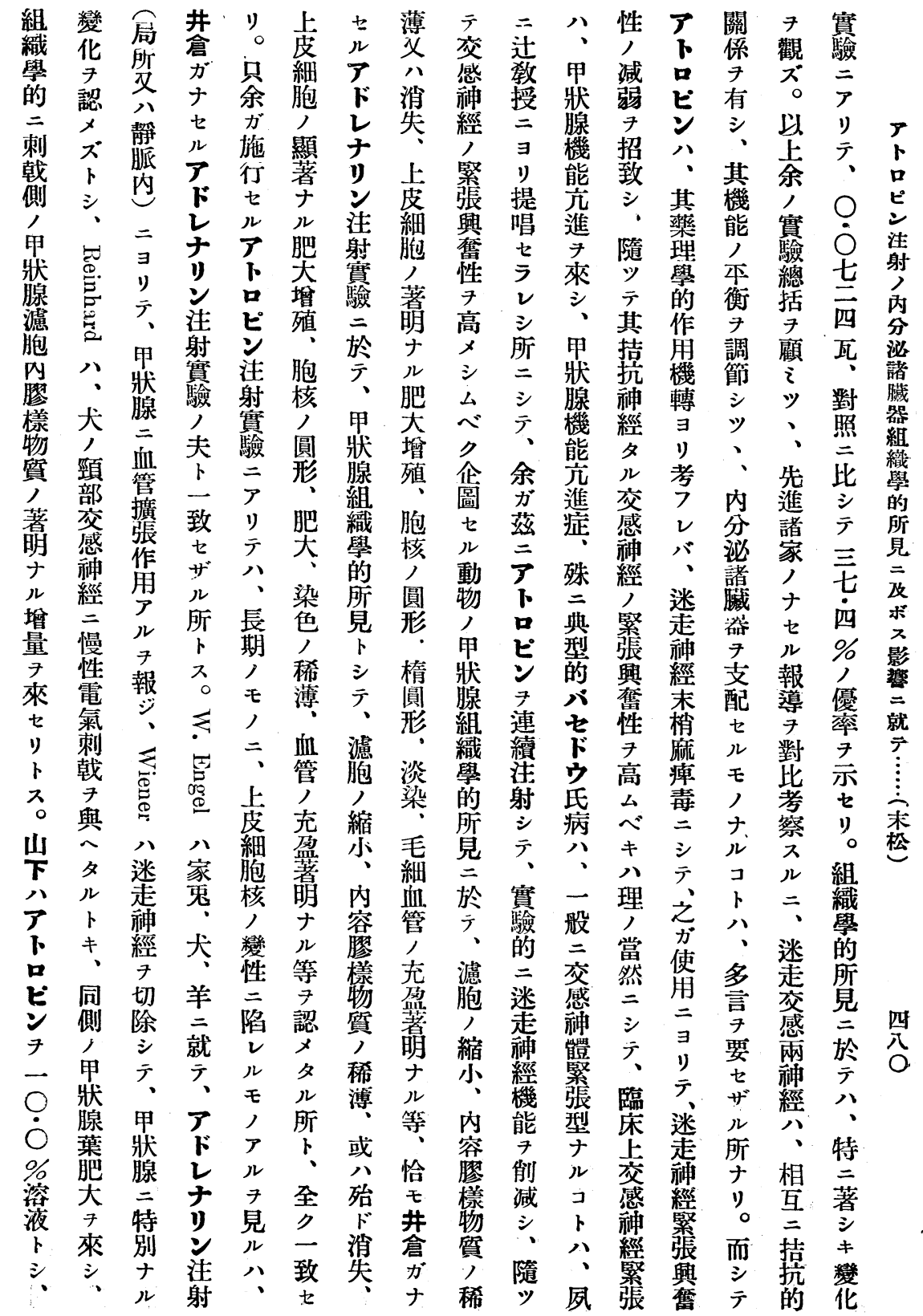




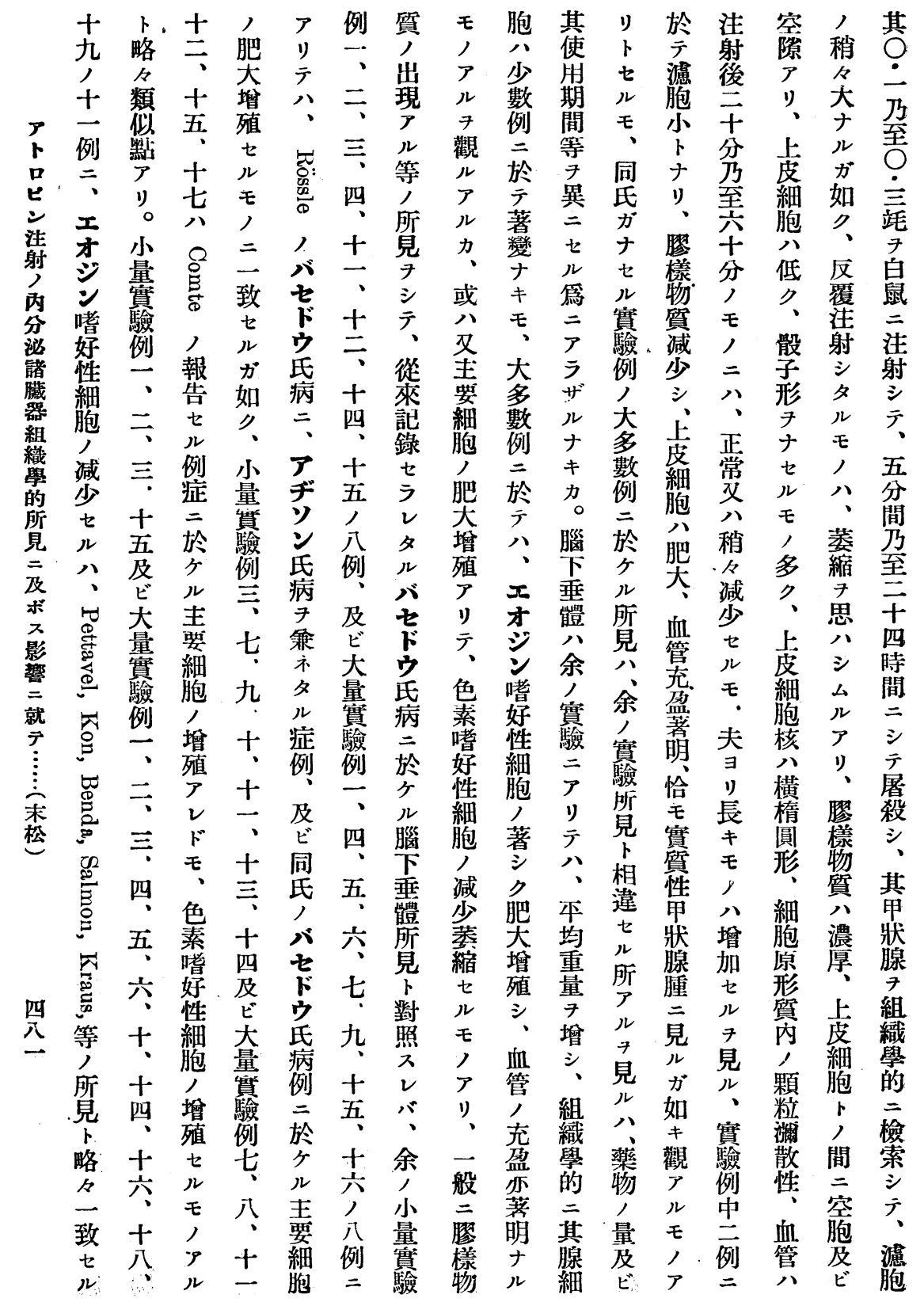




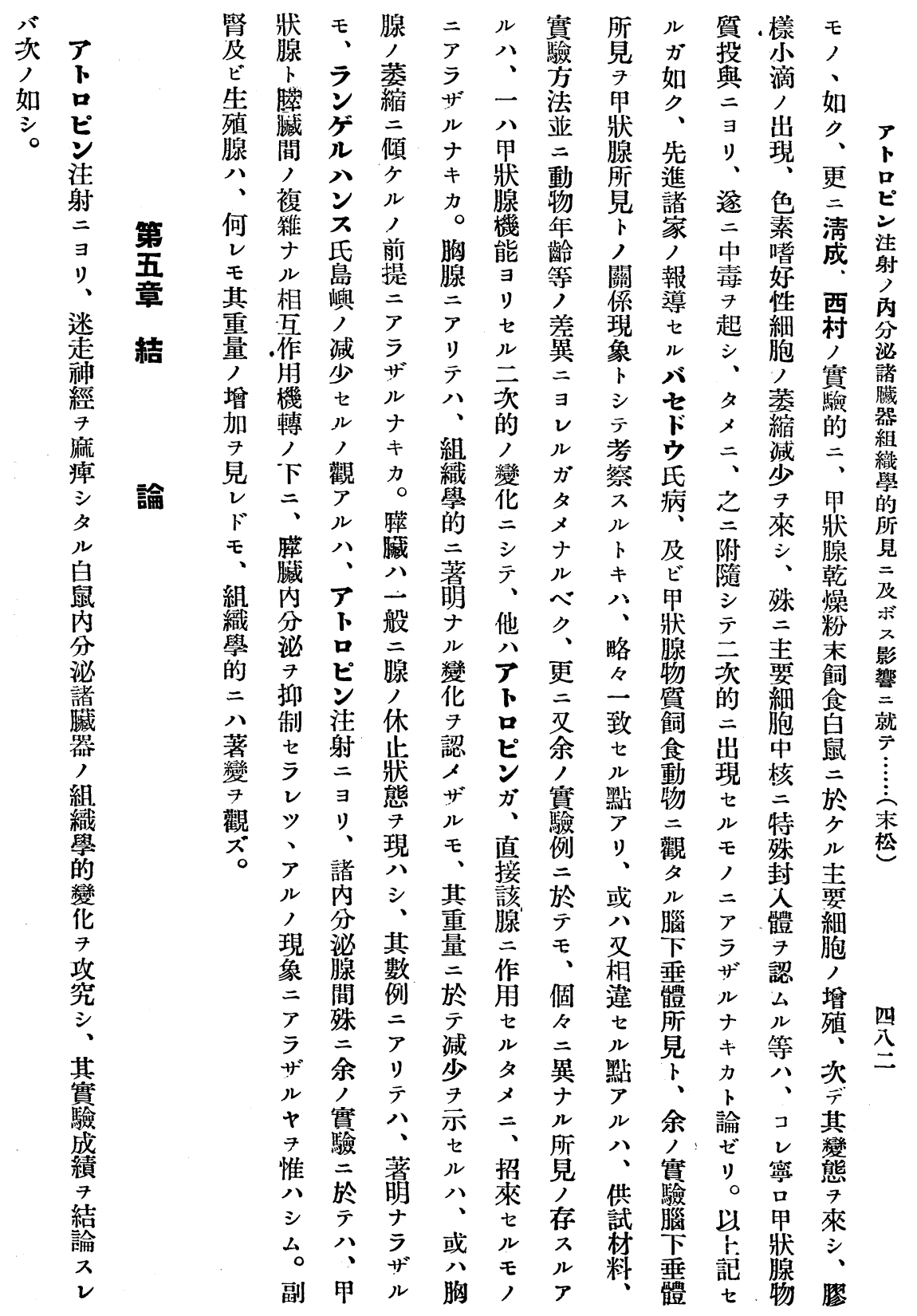




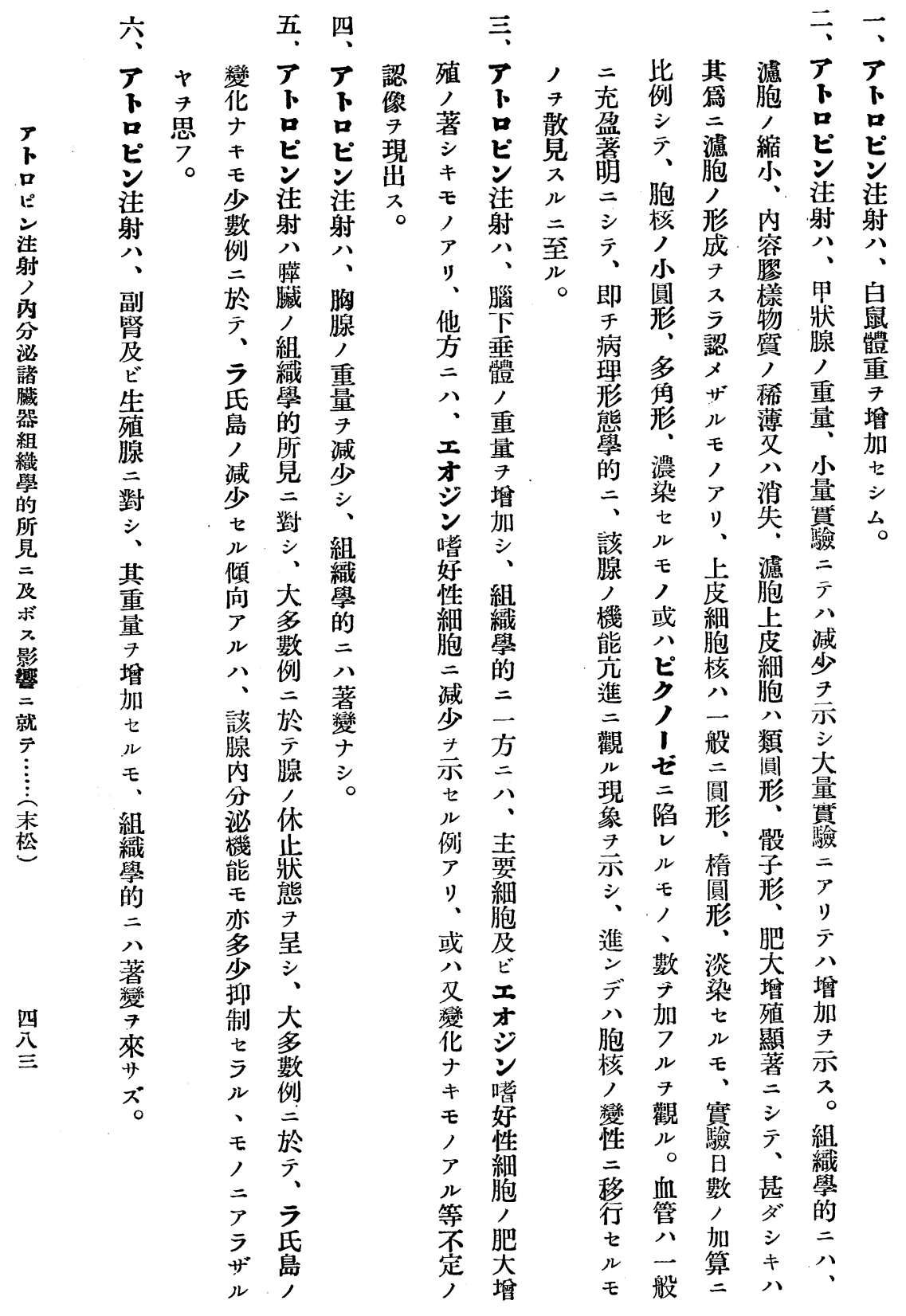




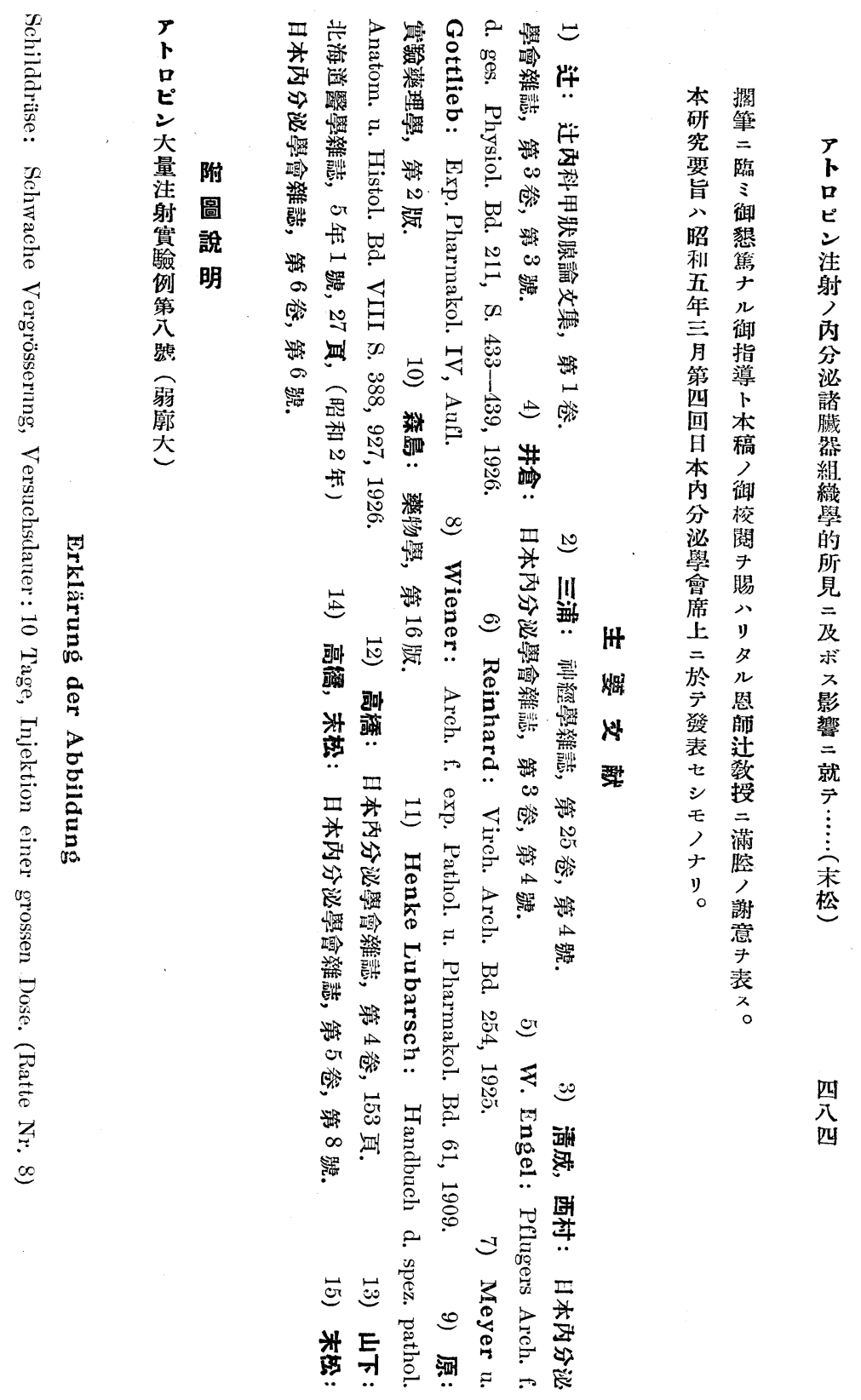


末

松

論

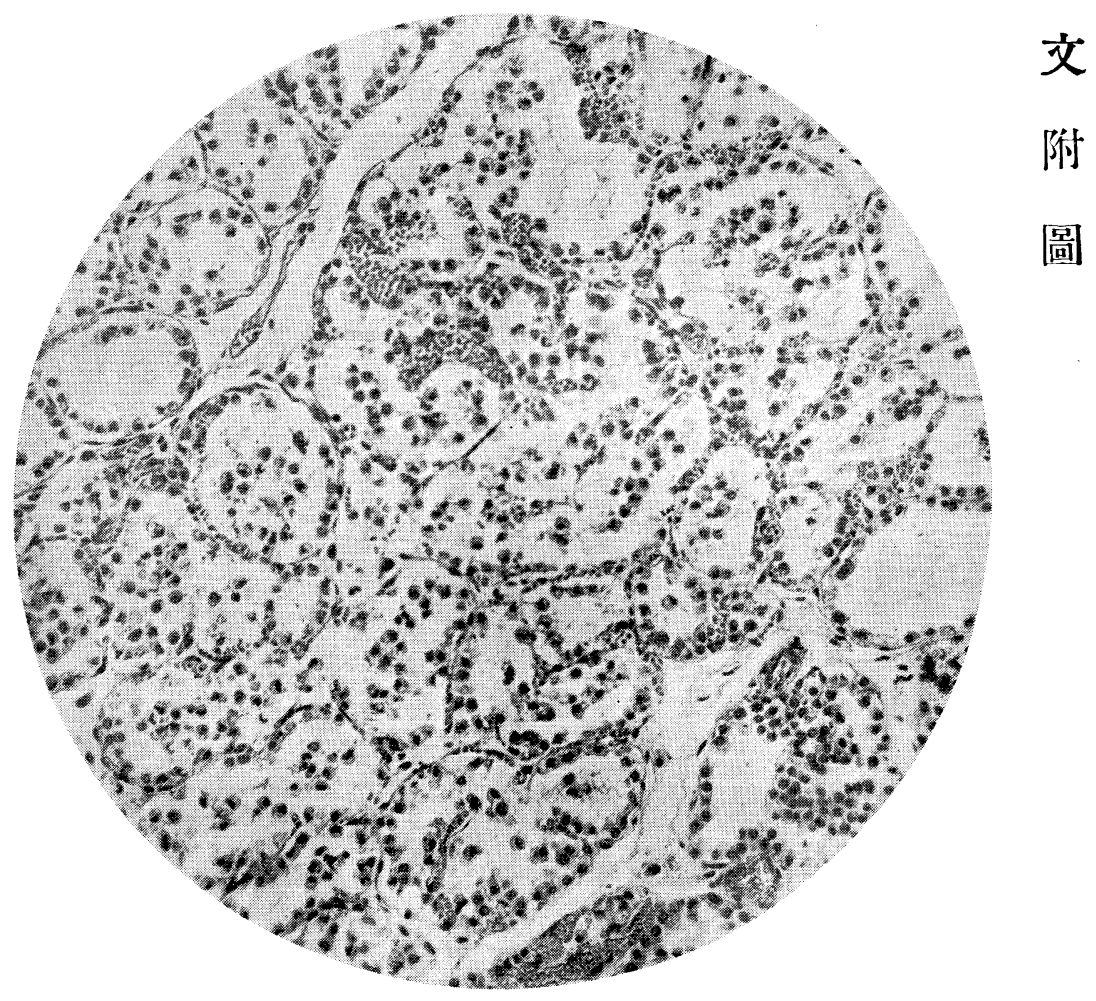


Von weissen Ratten, welchen 10 bis 60 Tage lang täglich 0.7 ecm Alttuberculin subkutan injiziert ${ }_{i}$ worden war, wurden die innersekretorischen Organe untersucht.

Die Resultate waren die folgenden:

1) Das Körpergewicht der Versuchstiere nahm stets nur ein wenig bis zum 50 Tage nach der Injektion zu und danach den Kontrolltieren gegenüber etwas ab.

2) Die Schilddrüse bei den 10 bis 40 Tage lang injizierten Fällen zeigte meist Gewichtsabnahme und das Bild des parenchymatösen Hyperthyreoidismus, dagegen bei über 50 Tage injizierten Fällen Gewichtszunahme und das Bild des Kolloidstrumas.

3) Die Hypophysis wies meist Gewichtszunahme auf und zeigte histologisch anfangs Hyperämie in allen Lappen, Verminderung der Hauptzellen und Vermehrung der Eosinophilen in dem Vorderlappen, aber später Hypertrophie der Hauptzellen und Verminderung der Eosinophilen in dem Vorderlappen.

4) Die Nebenniere nahm an Gewicht zu und liess häufig Hyperämie in der Rinde, aber keine regressiven Veränderungen erkennen.

5) An der Thymus hatte das Gewicht abgenommen, und im Endstadium waren histologisch geringgradige regressive Veränderungen zu konstatieren.

6) Die Geschlechtsdrüse war ohne nennenswerte Veränderungen.

(Autoreferat)

\section{Ueber den Einfluss der Atropininjektion auf die histologischen Befunde der innersekretorischen Organe.}

Von

Dr. T. Suematsu.

(Aus der I. med. Klinik der Kaiserl. Universität zu Kyoto, Japan.

Direktor: Prof. Dr. K. Tsuii.) 
Gesunde Ratten (K. G. 8C-200 g) wurden in 2 Gruppen geteilt. Der Verfasser injizierte den Ratten der einen Gruppe subkutan täglich pro $100 \mathrm{~g}$ K. G. $0.1 \mathrm{ccm} 0.05 \%$ iger Atropinlösung und denen der anderen Gruppe gleiche Dose $1.0 \%$ iger Lösung. Die beiden Gruppen wurden nach 10 oder 20 Versuchstagen getötet und die histologischen Veränderungen der endokrinen Organe untersucht.

Die Resultate waren wie folgt:

Körpergewicht und Organgewicht :

Das Körpergewicht des Versuchstieres nahm in Endstadium zu. Schilddrüse und Thymus nahmen an Gewicht ab, Hypophyse, Nebenniere, Ovarium und Hoden zu.

Histologische Befunde:

Die Schilddrüse zeigte im Anfangsstadium das Bild der Hyperfunktion (kleine Follikel, Abnahme oder Verschwinden der Kolloidsubstanz, Hypertrophie u. Hyperämie der Kapillargefässe). Endlich aber fand sich das Bild der regressiven Veränderungen an den Kernen der Epithelzellen (dicke Färbung und Pyknose des Kernes usw.)

Von den eosinophilen Zellen im Vorderlappen der Hypophyse wiesen manche Verminderung auf, andere dagegen Hypertrophie $u$. Hyperplasie und die basophilen Zellen im Vorderlappen Verminderung. Bei allen Fällen trat deutlich im Vorder-und Hinterlappen der Hypophyse Kolloidsubstanz auf.

An Thymus, Nebenniere, Hoden und Ovarium sah der Verfasser keine nennenswerte Veränderung.

(Autoreferat)

\section{Druckfehlerberichtigung :}

1) Bd. VI, Heft XII, (1931) Seite 117, Zeile 7 von oben muss es statt "Nebenhoden" "Nebennieren" heissen.

2) Bd. VII, Heft II, (1931), Seite 6, Zeile 2 von oben statt "Der Purinbasen-Harnsäure-Stickstoff Zeigt" Lies "Der PurinbasenHarnsäure-Stickstoff, besonders Allantoinstickstoff Zeigt" 